\title{
LAW as POLITICS
}





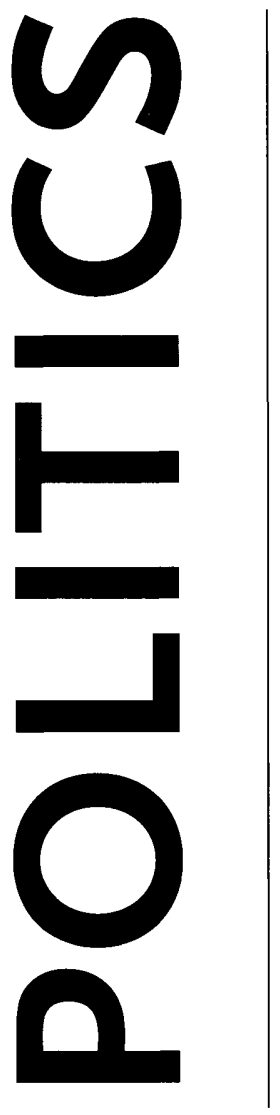

Carl Schmitt's

Critique of Liberalism

$\stackrel{\infty}{\sigma}$

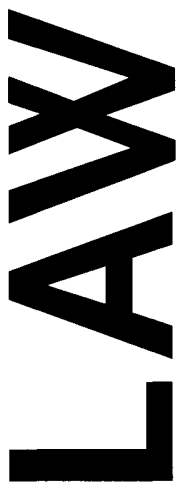

Edited by David Dyzenhaus

Foreword by Ronald Beiner

DUKE UNIVERSITY PRESS

DURHAM AND LONDON

I998 


\section{(c) 1998 DUKE UNIVERSITY PRESS}

All rights reserved I Printed in the United States of America on acid-free paper $\otimes$ । Typeset in Trump Mediaeval by Tseng Information Systems, Inc. I Library of Congress Cataloging-in-Publication Data appear on the last printed page of this book.

Grateful acknowledgment is made for permission to reprint the following material in this volume: | Ernst-Wolfgang Böckenförde, "Der Begriff des Politischen als Schlüssel zum staatsrechtlichen Werk Carl Schmitts," in Ernst-Wolfgang Böckenförde, Recht; Staat; Freiheit: Studien zur Rechtsphilosophie, Staatstheorie und Verfassungsgeschichte. (O) Suhrkamp Verlag Frankfurt am Main I99I. I William E. Scheuerman, "Revolutions and Constitutions: Hannah Arendt's Challenge to Carl Schmitt." (C) Rowen \& Littlefield Publishers, Inc., Lanham, Md., I998. I Portions of this volume were previously published in The Canadian Journal of Law and Jurisprudence, vol. Io, no. I (I997). 